\title{
燃料組成の過渡的変化が予混合火炎の挙動に及ぼす影響
}

\author{
鈴木 貴士 ${ }^{* 1}$, 佐藤 衛 $^{* 2}$ ，梅沢 修一 ${ }^{* 3}$ ，横森 剛 ${ }^{* 4}$ ，植田 利久 ${ }^{* 5}$
}

\section{Effect of a transition in a species fraction of fuel on the behaviour of a premixed flame}

\author{
Takashi SUZUKI ${ }^{* 1}$, Mamoru SATO*2, Shuichi UMEZAWA*3 ${ }^{*}$, Takeshi YOKOMORI ${ }^{* 4}$ \\ and Toshihisa UEDA*5 \\ ${ }^{*} 1,{ }^{*},{ }^{*} 4,{ }^{* 5}$ Faculty of Science and Technology, Keio University \\ 3-14-1 Hiyoshi, Kohoku-ku, Yokohama 223-8522, Japan \\ ${ }^{* 3}$ Tokyo Electric Power Company Holdings, Inc \\ 4-1 Egasaki-cho, Tsurumi-ku, Yokohama 230-8510, Japan
}

\section{Received: 14 April 2017; Revised: 8 August 2017; Accepted: 28 December 2017}

\begin{abstract}
Flame height variations of a laminar stagnating premixed flame with gas component transition between fuel mixture A (methane:92\%, ethane:6.7\%, propane:1.3\%) and $\mathrm{B}$ (methane:84\%, ethane:13.3\%, propane:2.7\%), and between $\mathrm{A}$ and $\mathrm{C}$ (methane:76\%, ethane:20.0\%, propane:4.0\%) are discussed. The estimation of the flame speed and the flame temperature of fuel mixtures $\mathrm{A}, \mathrm{B}$ and $\mathrm{C}$ by the Chemkin-Pro show almost the same values for all fuel mixtures. In experiments, the transition between $A$ and $B$ and between $A$ and $C$ were performed. The transition time changes from $1 \mathrm{~s}$ to $10 \mathrm{~s}$, keeping flow velocity and equivalence ratio constant at $0.8 \mathrm{~m} / \mathrm{s}$ and 0.7 respectively. The flame position was measured by using images taken by a high speed camera with 125 fps. Two transition patterns are examined, keeping the total flow rate of premixed mixture constant. One is the constant flow rate transition, which changes the gas component, keeping the fuel mixture flow rate constant. The other is the constant equivalence ratio transition, keeping the equivalence ratio constant. In the case of the constant flow rate transition, the equivalence ratio changes which results in the variation in the flame speed, the flame temperature and the flame height. It means that the combustion state changes with the transition. On the other hand, in the case of the constant equivalence ratio transition, the flame speed, the flame temperature and the flame height keep almost the same state, which means that the gas component can be changed, keeping the combustion state the same.
\end{abstract}

Keywords : Natural gas, Component ratio, Premixed flame, Stagnation flame, Transition phenomena

\section{1. 緒言}

地球温暖化防止のため，各国で二酸化炭素の排出量削減の対策が行われている．風力や太陽光といった自然工 ネルギーが近年急速に普及しているが，それだけでは全エネルギーを賄うことはできず，今後も少なくとも数十 年間は化石燃料の燃焼に頼らざるを得ない状況である. 化石燃料の中でも, 天然ガスは C/H 比が小さいメタンを 主成分とし，石油や石炭に比べ二酸化炭素排出量が少ないことから，天然ガスへの燃料転換が活発に行われてい る.また，これまでコストや技術面から採掘が困難であった非在来型と呼ばれる天然ガスの可採埋蔵量が伸びて おり (U.S Energy Information Administration, 2013)，今後の一層の天然ガス利用が予想される．資源輸入国である日 本においては然料の安定供給のため複数の輸入先を確保することが望ましい. また，天然ガスは同じ国であって

No.17-00168 [DOI:10.1299/transjsme.17-00168], J-STAGE Advance Publication date : 16 January, 2018

${ }^{* 1}$ 慶應義塾大学 大学院理工学研究科（广223-8522 神奈川県横浜市港北区日吉 3-14-1)

*2 慶應義塾大学 理工学部機械工学科

*3 正員, フェロー， (株) 東京電力ホールディングス（†230-8510 神奈川県横浜市鶴見区江ケ崎町 4-1）

${ }^{* 4}$ 正員, 慶應義塾大学 理工学部

*5 正員, フェロー, 慶應義塾大学 理工学部

E-mail of corresponding author: ueda@mech.keio.ac.jp 
も井戸元によっても成分比が異なるため, 成分比と燃焼特性の関係の定量的な理解が重要となる. Huang ら (2006) は，天然ガスに水素を添加した場合の層流然焼速度の変化について実験的に検討を加えている，そして，水素の 体積分率を増加させると層流燃焼速度が飛躍的に増加することを明らかにしている．また，Bourque ら（2009） は, メタンをべースに，C1 から C5 までの炭化水素を含む多成分燃料に関して, 着火遅れ時間ならびに層流然焼 速度の特性について実験的に検討を加えている，そして，分子量の大きい炭化水素を加えると，層流燃焼速度が 増加することを示している．これらの研究では，定常的な燃焼特性の変化に着目している．非定常的な燃焼特性 の変化に関して，著者らは，これまでに予混合気の当量比の周期的変動が燃焼挙動に及ぼす影響について検討を 加えてきた. その結果, 変動周波数が小さいとき, 火炎は当量比の変動に対して準定常的に変化するが, 周波数 が, ストローハル数が 1 となる周波数を超えると非定常的な火炎挙動を示すことを明らかにしてきた（Miyamae ら, 2014, Rosdzimin ら, 2015, Tomita ら, 2015, Kawasaki ら, 2016). 他方, 過渡的な燃料成分变化に関しては, 当量比の過渡的な変動に対する燃焼特性の応答性に関する研究（Marzouk ら, 2000） があり, Back support 効果 が燃焼特性に重要な役割を演じていることを示唆している．しかしながら，燃焼機器を連続運転しながら異なる 成分比の天然ガスを切り替える際に，火炎挙動にどのような影響が表れるかについてはほとんど検討されていな い. そこで, 本研究では, 組成が異なる天然ガスが貯蔵されている 2 つ燃料タンクの切り替えを燃焼中に行う ことを想定し，燃料組成の過渡的な変化が予混合火炎の挙動に及ぼす影響について検討することを目的とする. 本研究では，火炎の基礎特性に着目するため，火炎基部を持たず火炎構造が比較的単純な層流よどみ流予混合火 炎を対象とする。

\section{2. 装置および方法}

\section{$2 \cdot 1$ 混合燃料の組成の決定}

天然ガスは，一般的にメタンを主成分とする混合燃料であるが，その化学種の種類とその成分比は，表 1 にそ の一例を示すように産地によって異なる（The International group of liquefied natural gas importers, 2016). 表 1 より 明らかなように, LNG として輸入される天然ガスの主成分はメタンであり, 少量成分としてエタン, プロパンが 含まれる，その他の成分は極微量である，そこで本研究では，表 2 に示すように，メタン，エタン，プロパンの 3 成分に着目し，メタンの濃度が表 1 の天然ガスの中間的な值となるように組成 $\mathrm{A}$ を定め，さらに，エタン，プ ロパンが組成 A の 2 倍程度含まれる組成 B と 3 倍程度含まれる組成 C を設定した. ここで, エタンとプロパン の比率を 5:1 とした. その結果, メタンのモル分率の変動幅は $92 \%$ から $76 \%$ となり, 発熱量差は 6 $\mathrm{MJ} / \mathrm{m}^{3}$ 程度と なった.

Table 1 Fuel ratio in Natural gases. [Mole percent] （The International group of liquefied natural gas importers, 2016）

\begin{tabular}{|c|c|c|c|c|c|}
\hline Origin & $\mathrm{CH}_{4}[\mathrm{~mol} \%]$ & $\mathrm{C}_{2} \mathrm{H}_{6}[\mathrm{~mol} \%]$ & $\mathrm{C}_{3} \mathrm{H}_{8}[\mathrm{~mol} \%]$ & $\mathrm{C} 4+[\mathrm{mol} \%]$ & Nitrogen [mol \%] \\
\hline Alaska & 99.71 & 0.09 & 0.03 & 0.01 & 0.17 \\
\hline Indonesia & 96.91 & 2.37 & 0.44 & 0.15 & 0.01 \\
\hline Norway & 92.03 & 5.75 & 1.31 & 0.45 & 0.46 \\
\hline Algeria & 88.93 & 8.42 & 1.59 & 0.37 & 0.71 \\
\hline Libya & 82.57 & 12.62 & 3.56 & 0.65 & 0.59 \\
\hline
\end{tabular}

Table 2 Fuel volume ratio in the fuel mixture.

\begin{tabular}{|c|c|c|c|c|}
\hline & $\mathrm{CH}_{4}[\mathrm{~mol} \%]$ & $\mathrm{C}_{2} \mathrm{H}_{6}[\mathrm{~mol} \%]$ & $\mathrm{C}_{3} \mathrm{H}_{8}[\mathrm{~mol} \%]$ & $\begin{array}{c}\text { High heating } \\
\left.\text { value[MJ/m }{ }_{\mathrm{N}}\right]\end{array}$ \\
\hline $\mathrm{A}$ & 92 & 6.67 & 1.33 & 42.79 \\
\hline $\mathrm{B}$ & 84 & 13.33 & 2.67 & 45.65 \\
\hline $\mathrm{C}$ & 76 & 20.00 & 4.00 & 48.50 \\
\hline
\end{tabular}




\section{$2 \cdot 2$ 数值解析法}

燃料の基本燃焼特性の違いをみるために，Chemkin-Pro （2013）を用いて，実験と同様の層流よどみ流予混合 火炎を対象に, 定常状態における火炎速度と火炎温度を求めた. 計算条件としては, 圧力は大気圧 $0.1 \mathrm{MPa}$ とし, 予混合気のバーナ出口流速を $0.8 \mathrm{~m} / \mathrm{s}$, 出口温度を $298.15 \mathrm{~K}$, 当量比を 0.7 とた。.また，よどみ板温度は，実験 結果を参考に $800 \mathrm{~K}$ 一定とした. バーナ出口とよどみ板との距離は, 2 ・3 節に述べる実験装置に準じて $21 \mathrm{~mm}$ と した. 反応モデルには NUI Galway のモデル（Bourque et al., 2009）を用いた. この反応モデルは天然ガス用に開 発されたものであり，モデルの妥当性は実験との比較から確かめられている.

図 1 に，計算結果の一例を示寸，層流よどみ流予混合火炎を対象としているため，予混合気流速はバーナ出口 から下流に向かって減少し，火炎帯付近で極小值をとり，急上昇する．また，温度は火炎帯付近で急上昇する. そこで，従来から広く用いられてきた方法を参考に（Law, 1989），火炎速度は火炎帯前縁で予混合気流速が極小 值となる位置の流速，火炎温度は火炎帯後方で温度が最高となる位置の温度とした。

また，この反応モデルを用いて，モデルの妥当性を検証するために，メタン/空気，エタン/空気，プロパン/空 気混合気について計算を行い，文献值との比較を行った。 その結果を表 3 に示寸. 計算は, 当量比 1 の場合につ いて行った，比較值として，メタン，プロパンに関しては，Yamaoka and Tsuji（1984）の文献值を，エタンに関し ては，Mituら（2015）の文献值を用いた。また，断熱火炎温度に関しては，Hikita and Akita（1974）の值を用い た. 断熱火炎温度に関しては, 文献值と計算值の誤差は最大 $\pm 1 \%$ 程度である. 層流燃焼速度に関しては, 最大土 3\%以内であり, 実験精度などを考えると, 十分な精度で計算されていることがわかる. この結果より, 本研究で 用いた反応モデル NUI Galway は, 個々の燃料についても十分な精度を有するモデルであることが確かめられた。

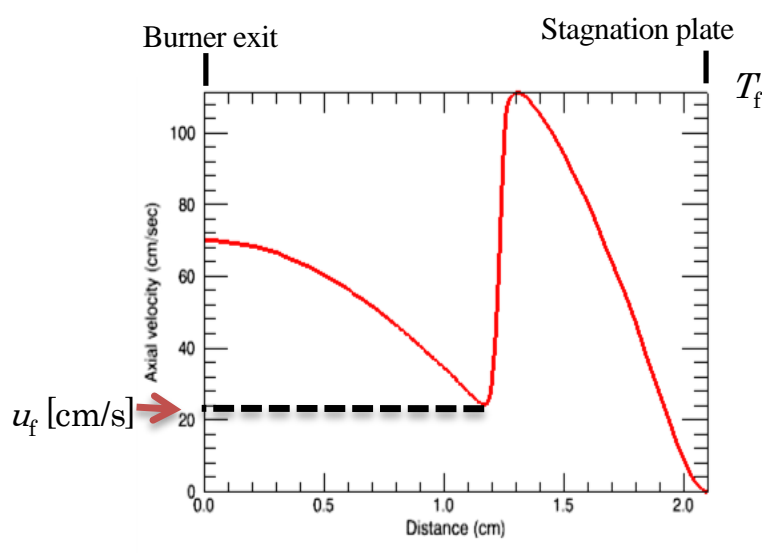

(a) Axial velocity distribution

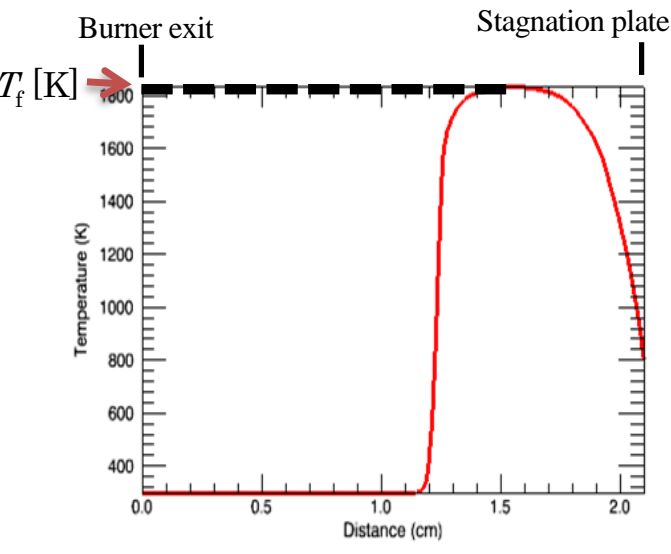

(b) Temperature distribution

Fig. 1 Numerical resut of the axial velocity and temperature distributions in the laminar stagnation premixed flame

Table 3 Flame speed and flame temperature at the equivalence ratio 1 for methane/air, ethane/air and propane/air mixtures

\begin{tabular}{|c|c|c|c|c|}
\hline Fuel & $\begin{array}{c}\text { Flame speed } \\
\text { calculated }(\mathrm{cm} / \mathrm{s})\end{array}$ & $\begin{array}{c}\text { laminar burning } \\
\text { velocity }(\mathrm{cm} / \mathrm{s})\end{array}$ & $\begin{array}{c}\text { Flame } \\
\text { temperature } \\
\text { calculated }(\mathrm{K})\end{array}$ & $\begin{array}{c}\text { Adiabatic flame } \\
\text { temperature (K) }\end{array}$ \\
\hline Methane & 37 & 39 & 2210 & 2240 \\
\hline Ethane & 37 & 40 & 2250 & 2240 \\
\hline Propane & 43 & 42 & 2250 & 2250 \\
\hline
\end{tabular}

\section{$2 \cdot 3$ 実験装置および方法}

図 2 に, 本研究で用いた層流よどみ流予混合火炎実験装置を示す. 本装置はよどみ板と予混合気を噴出するバ 一ナから構成されている，層流よじみ流予混合火炎は火炎基部を持たず，火炎が平面状に形成されるため，火炎 
構造が単純で火炎の基礎特性の検討に適している. バーナ内径は $20 \mathrm{~mm}$ ，バーナ出口とよどみ板との距離は 21 $\mathrm{mm}$ である. 座標 $x$ は, バーナ出口中心を原点とし, 流れ下流方向を正とした. 図 3 に空気, 燃料供給系を示寸. メタン，エタン，プロパンおよび空気の流量はそれぞれマスフローコントローラにより独立に設定される．マス フローコントローラには，すべて AZBIL MQV シリーズ（応答時間 : 設定 $\pm 2 \% F S$ 以内に $0.3 s （ F S:$ フルスケー ル）を使用した. マスフローコントローラにより流量を設定された予混合気は, 図 2 に示すバーナ下部の 4 か所 から流入しビーズ（直径 $8 \mathrm{~mm}$ ）により整流される. その後縮流部を通り，一様速度分布となりハニカム，メッシ ユにより整流されバーナから流出される．外気と予混合気の剪断力の影響を小さくするため，また，バーナへの 火炎基部の付着を防ぐため，バーナ周囲から Co-flow として窒素が定常的に流されている. 図 4 に，形成された 火炎の一例を示す．形成された火炎をバーナ中心軸に直角な方向からハイスピードカメラにより $125 \mathrm{fps}$ で撮影 した．図 4 より，よどみ板に平行に定常な平面予混合火炎が形成されていることわかる．撮影された画像におい て, 火炎位置(flame position)はバーナ軸上で青色成分の輝度が最も高い位置とし. 火炎高さ $x_{\mathrm{f}}$ は, 座標系を図 2 に 示すように定義していることから, 図4 に示すようにバーナ出口から火炎位置までの距離となる.

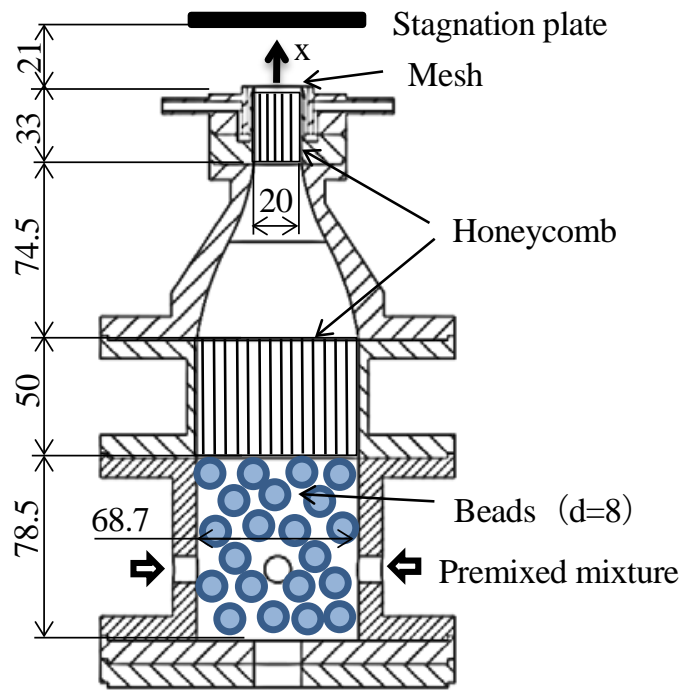

Fig. 2 Burner system

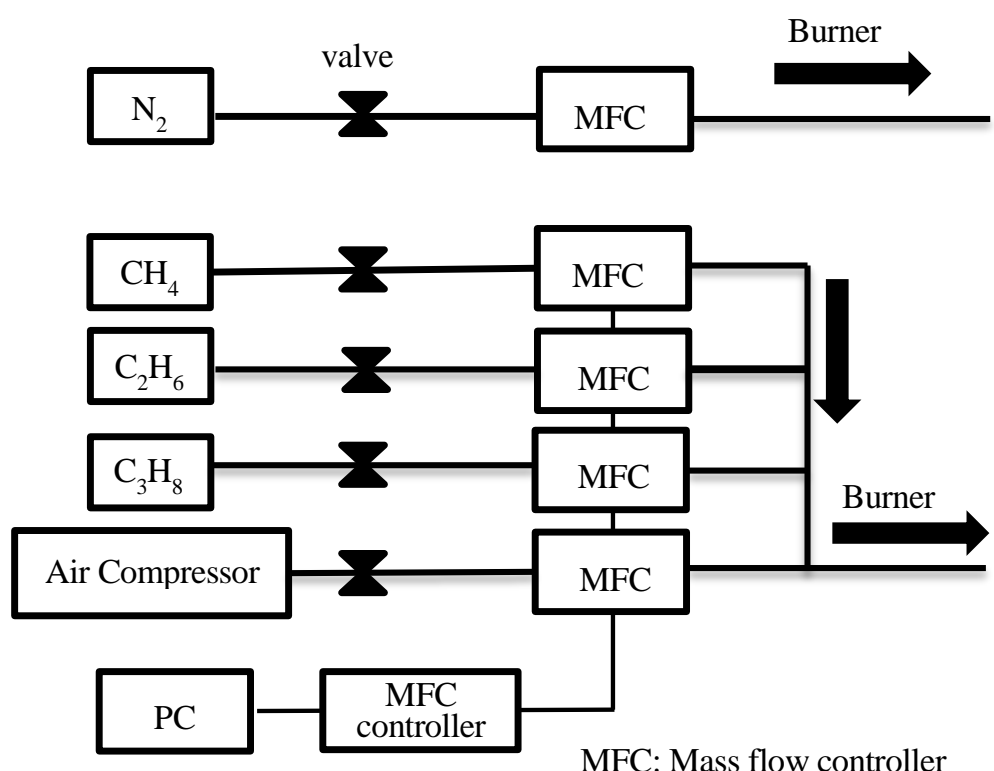

Fig. 3 Flow control system

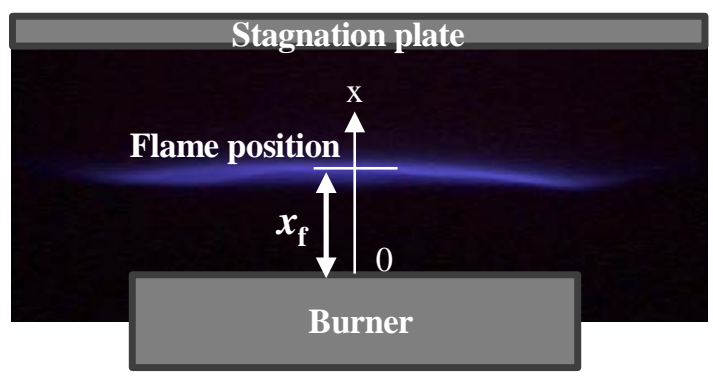

Fig. 4 Snap shot of the flame

\section{$2 \cdot 4$ 混合燃料切り替え方法}

本研究では, 表 2 に示した混合燃料を過渡的に切り替える. 図 5 に切り替え前後の空気流量, 混合燃料流量, 総流量の関係を示寸。 
燃料切り替え方法としては，総流量を一定として，混合燃料流量を変化させずに，混合燃料 1 から混合燃料 2 に切り替える場合 (流量一定の場合) と当量比を一定に保つように混合燃料流量と空気流量を変化させる場合 (当 量比一定の場合）の 2 種類の切り替え方法について検討を加えた.

流量一定の場合，総流量を一定としていることから空気流量は変化させない．この場合，混合燃料 1 と 2 とで は, メタン, エタン, プロパンの比率が異なることから, 当量比は変化する. 他方, 当量比一定の場合では, 総 流量を一定に保ちながら, 混合燃料 1 と 2 の流量を切り替えると同時に, 当量比を一定に保つように空気流量を 変化させる.

流量一定の方法では, タンクの切り替えは, それぞれのタンクから燃料流量がかわらないようにバルブ切り替 えを行うことにより実現できることから，もっとも現実的な切り替え方法であると考えることができる．ただし この場合，末端の燃焼機器では，空気流量の調整を行わないので当量比が変化することになる．他方，当量比一 定の場合, タンクの切り替えの際に，その変化に対応して末端の機器では空気流量も調整する必要がある.

実験においては，切り替えは，図6に示すように，マスフローコントローラにより各燃料の流量を線形的に変 化させ, 混合燃料 1 と 2 を設定時間で線形的に切り替える. 流量一定の場合, 混合燃料流量が一定となるように, 図 6(a)のように切り替える. 一方, 当量比一定の場合, 図 6(b)に示すように混合燃料の流量が変化するため, 総 流量を一定にし, なおかつ当量比が一定となるように空気流量も変化させる. 総流量は, バーナ出口 $(x=0)$ に おける予混合気流速が $0.8 \mathrm{~m} / \mathrm{s}$ 一定となるように設定する. また，切り替え時間 $t_{\mathrm{c}}$ は $1 \mathrm{~s} ， 5 \mathrm{~s} ， 10 \mathrm{~s}$ とした.

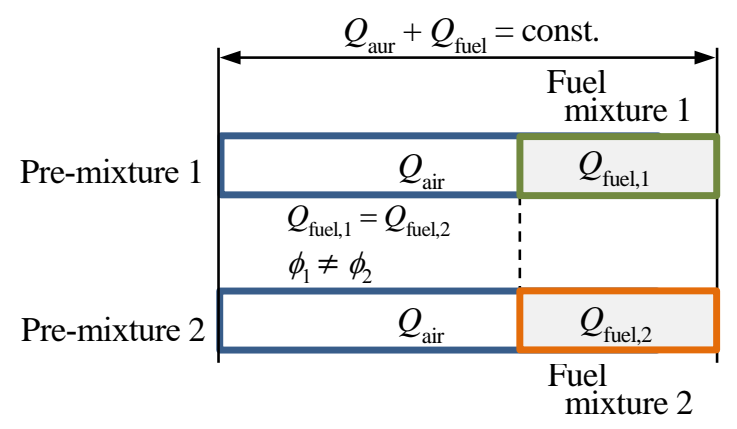

(a) Flow rate constant $\left(\phi_{1} \neq \phi_{2}\right)$

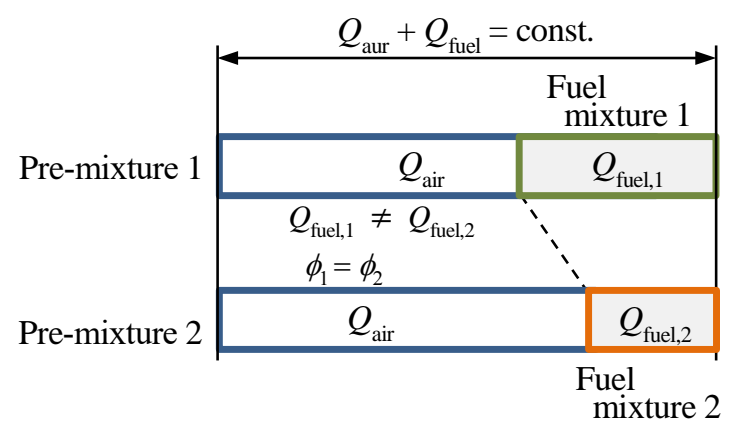

(b) Equivalence ratio constant $\left(\phi_{1}=\phi_{2}\right)$

Fig. 5 Fuel mixture change pattern

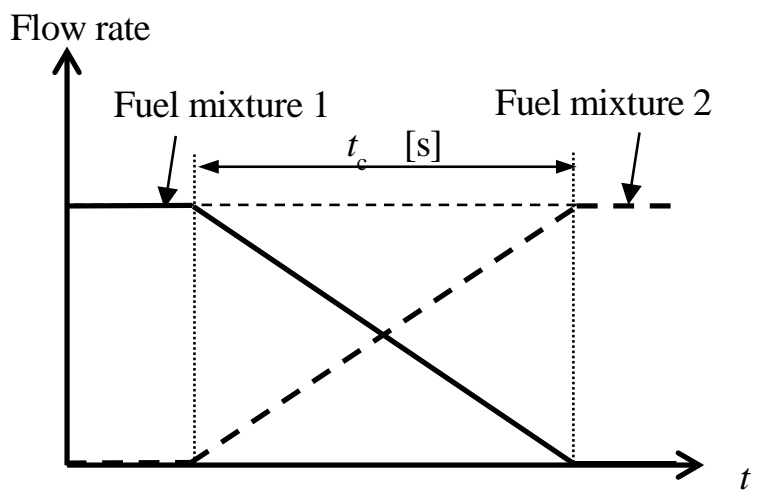

(a) Flow rate constant $\left(\phi_{1} \neq \phi_{2}\right)$

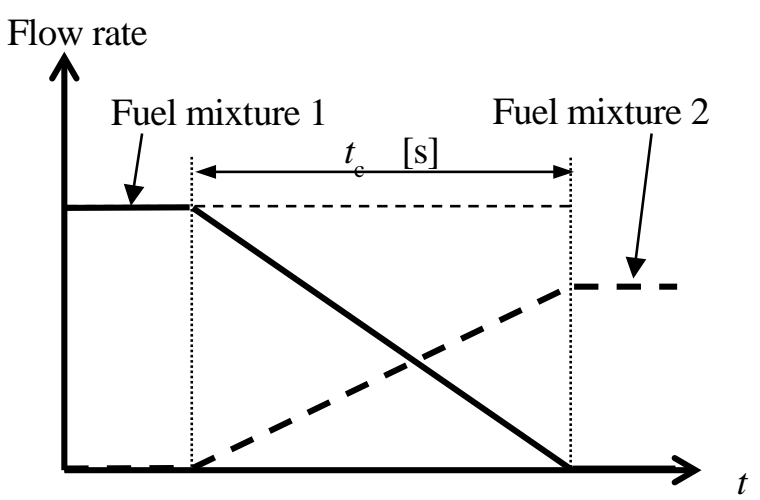

(b) Equivalence ratio constant $\left(\phi_{1}=\phi_{2}\right)$

Fig. 6 time variation in the fuel mixturse

\section{3. 結果及び考察}

\section{$3 \cdot 1$ 流量一定の場合}




\section{$3 \cdot 1 \cdot 1$ 火炎速度, 火炎温度の変化}

2 ・4節にも述べたが，流量一定とは，混合燃料の切り替えの際，空気流量を一定に保ちながら，燃料流量が一 定になるように切り替える場合である。したがって, バーナ管から噴出される予混合気の総流量は一定に保たれ る. 図 7 に, 混合燃料の流量を一定に保ったまま混合燃料 B から A に切り替えた場合を想定し, 混合燃料 A と B の予混合気の火炎速度と火炎温度の変化を Chemkin-Pro によって計算した結果を示す. 混合燃料 B から, メ夕 ンが多く, エタン, プロパンが少ない混合燃料 A に切り替えると, 当量比が減少し, 火炎速度, 火炎温度とも減 少することがわかる．また，混合燃料 B の当量比が 0.6 という，もっとも希薄な状態から混合然料 A に切り替え た場合，結果を得ることができなかった，これば，火炎が維持できなくなり，消炎することを示唆している.

\section{$3 \cdot 1 \cdot 2$ 実験結果}

\section{(1) 予混合気特性の変化}

今回使用したマスフローコントローラは，流量の時間的変化を設定できると同時に，実際の流量を電気信号 として取り出すことができる. 図8に，その信号を用いて，マスフローコントローラが実際に流している燃料， 空気の流量から算出した，流量一定の場合のバーナ出口流速と当量比の変化を示す．切り替えは， $\mathrm{t} \sim 3 \mathrm{~s}$ から 4 $\mathrm{s}$ の1秒の間に行われた。 図 8(a)より, バーナ出口流速は, 混合燃料を切り替えている間においても一定に保 たれていることがわかる，当量比は，変化前は 0.7 に設定しているが， $\mathrm{t} \sim 3 \mathrm{~s}$ から変化が開始すると燃料成分の
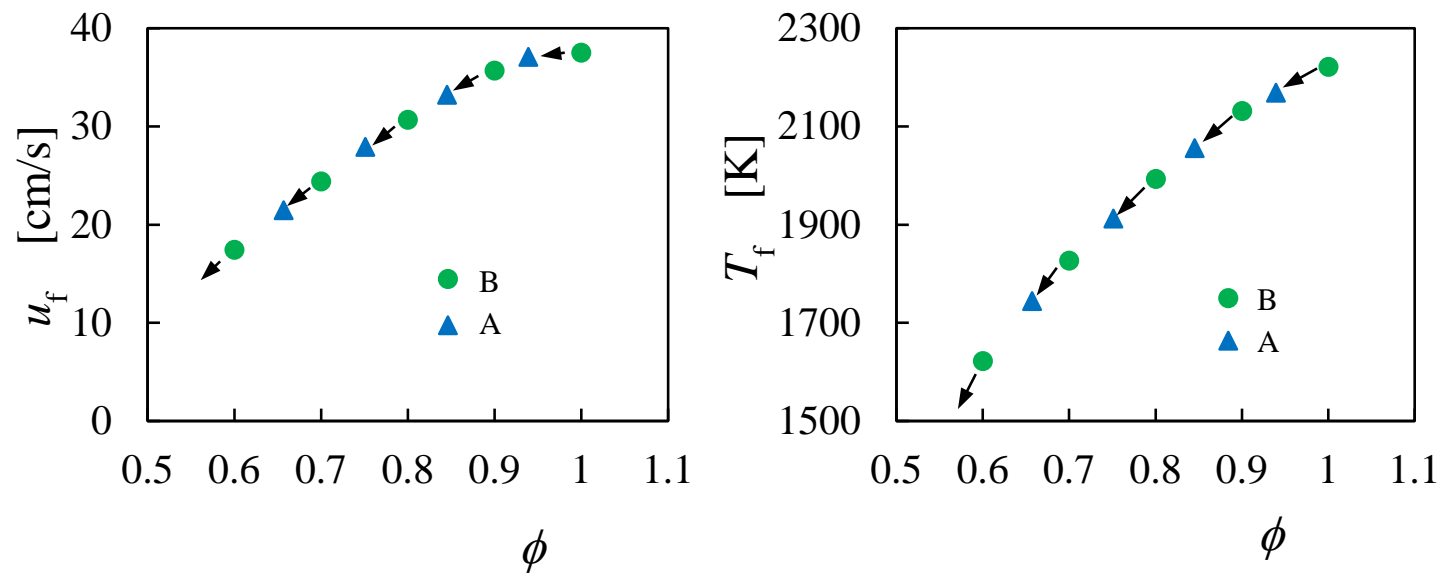

Fig. 7 Change in the flame speed and flame temperature in the flow rate constant case

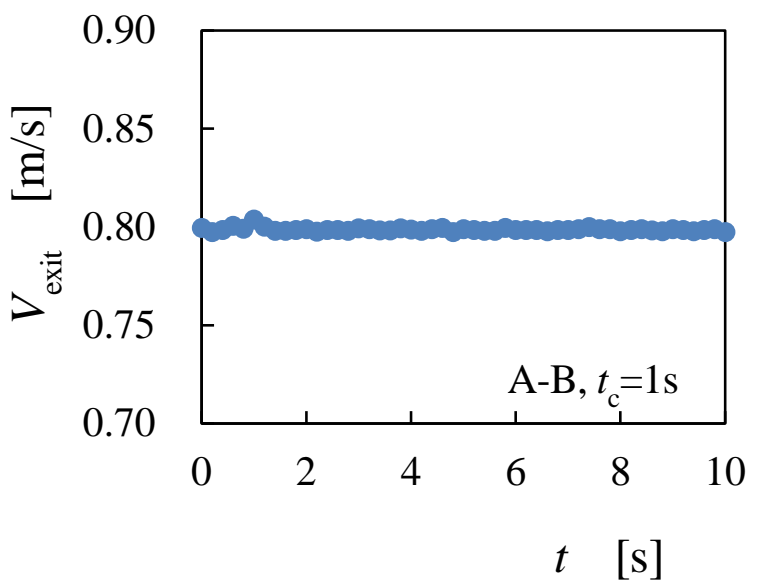

(a) Burner exit velocity

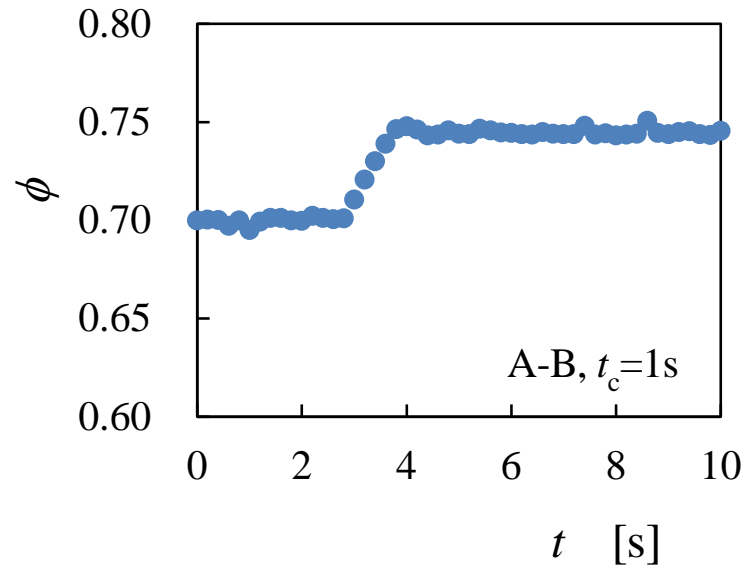

(b) Equivalence ratio

Fig. 8 Change in the burner exit velocity and the equivalence ratio in the flow rate constant case 比率が変化することから, 当量比も変化し始める. そして $\mathrm{t} \sim 4 \mathrm{~s}$ で変化が終了すると変化後の当量比で一定とな る. その間，線形的に変化していることがわかる. 


\section{$3 \cdot 1 \cdot 3$ 火炎高さ変化}

図 9 に，混合燃料 A と B を切り替えた場合の火炎高さの変化を示寸. (a) に A から B に切り替えた場合，(b) に B から A に切り替えた場合を示す，混合燃料の流量，空気流量を一定とした場合，混合燃料 A よりも混合燃 料 B のほうが，メタンが少なくエタン，プロパンが多くなることから，図 8(b)に示すように当量比が増加する. その結果，図 7(a)に示すように混合燃料 B の火炎速度は混合然料 A の火炎速度より大きくなる，その結果，図 9(a)のように火炎はバーナ出口に近づく. そして, 混合燃料 B から A に切り替えられる場合, 火炎はバーナ出口 から離れる. 火炎高さは，混合燃料 A から B に切り替えられる場合も混合燃料 B から A に切り替えられる場合 もほぼ線形に変化しており，その変化時間は切り替え時間に対応している.

図 10 に，混合燃料 A と C を切り替えた場合の火炎高さの変化を示す. (a) に A からCに切り替えた場合，(b) にCから A に切り替えた場合を示寸．混合燃料 C は混合然料 B よりもメタンがより少なく, エタン, プロパン がより多くなっていることから, 図 9 の混合然料 A と B を切り替えた場合に比べて火炎高さの変化幅が大きく なっている. また, 混合燃料 C から A に切り替えた場合, 当量比が 0.7 よりさくなり，本バーナにおける希薄 可燃限界を下回ることになり，消炎している．このことは，流量一定で切り替えた場合，当量比が変化すること になり，燃焼の状態が変化することを示しており，火炎が維持できなくなり，消炎することもあることを示して いる.この結果は，図 7 に示した数值計算結果に示した，火炎速度，火炎温度の変化の結果とも対応している.

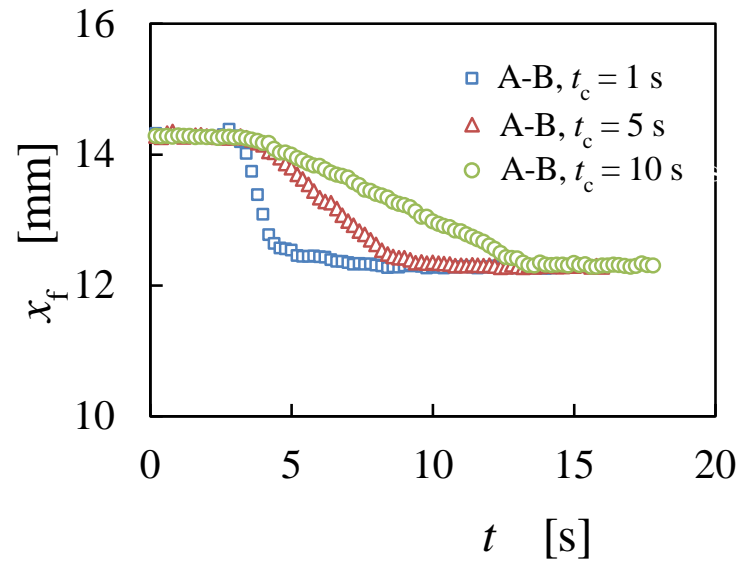

(a) Fuel mixture A to B

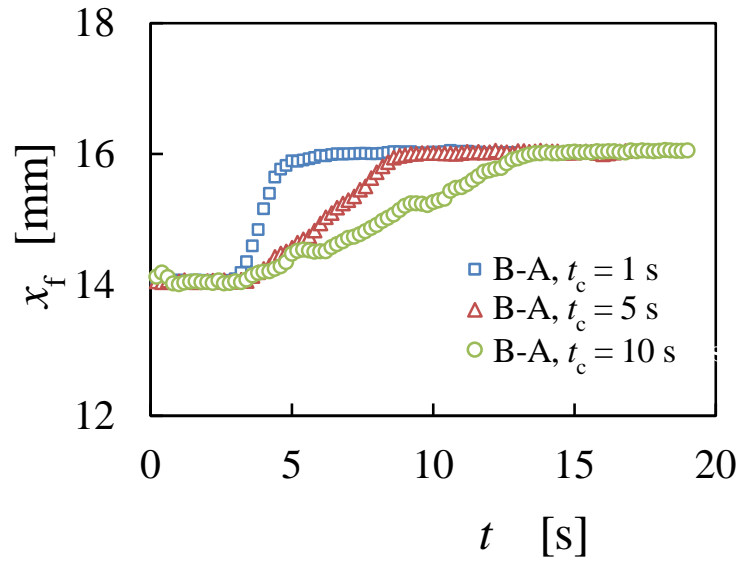

(b) Fuel mixture $\mathrm{B}$ to $\mathrm{A}$

Fig. 9 Change in the flame height with the change in the fuel mixture $\mathrm{A}$ and $\mathrm{B}$ as a function of $t_{\mathrm{c}}$

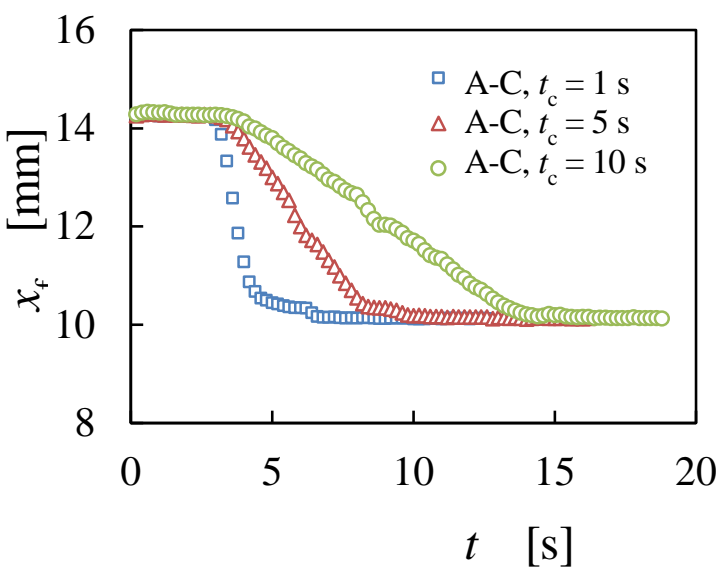

(a) Fuel mixture A to $\mathrm{C}$

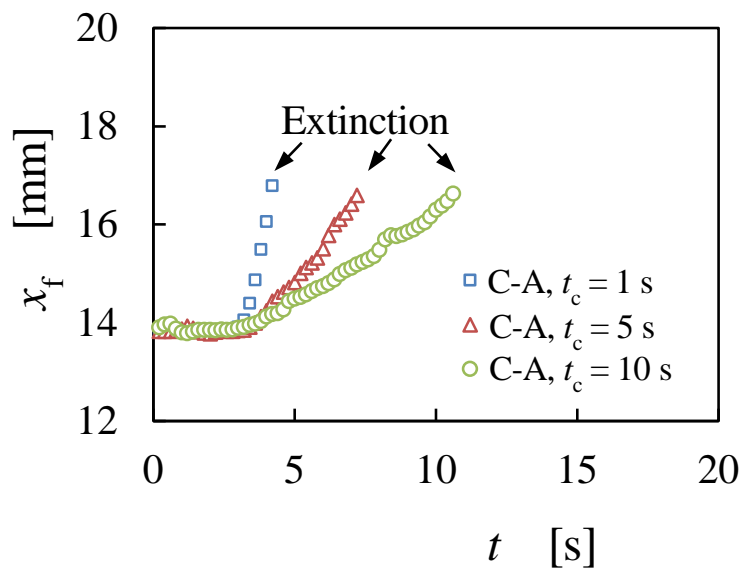

(b) Fuel mixture $\mathrm{C}$ to $\mathrm{A}$

Fig. 10 Change in the flame height with the change in the fuel mixture A and $\mathrm{C}$ as a function of $t_{\mathrm{c}}$

\section{$3 \cdot 2$ 当量比一定の場合}

\section{$3 \cdot 2 \cdot 1$ 火炎速度, 火炎温度の変化}


図 11 に，混合燃料 A，B，Cの予混合気の火炎速度，火炎温度の当量比による変化を示寸．どの混合燃料の場 合も，当量比が同じであれば，火炎速度，火炎温度ともにほとんど変化していないことがわかる．混合気 A と B を比較すると, 当量比一定とすると, 本研究では発熱量の大きい混合燃料 B の流量が A よりも少なくなり, 結果 として火炎に供給される熱量がほぼ等しくなる，すなわち，混合燃料 B の場合，当量比 0.7 では発熱量は， [燃 料のモル分率 $] \times$ [燃料 A の高位発熱量 $]=0.064 \times 45.66 \mathrm{MJ} / \mathrm{m}^{3}=2.92 \mathrm{MJ} / \mathrm{m}^{3}$, 混合燃料 A の場合も同様に, $0.069 \times 42.57 \mathrm{MJ} / \mathrm{m}^{3}=2.94 \mathrm{MJ} / \mathrm{m}^{3}$ となり, 実際に火炎に供給される熱量差は, 混合燃料 A と B の表 2 に示寸高位発 熱量の差より小さく，ほぼ同程度となっていることが分かる，その結果，火炎速度，火炎温度についてもほとん ど変化しなかったと考えることができる，この結果は，成分比が異なり，発熱量が異なる混合燃料の燃焼特性に たいしては, 当量比が重要なパラメータであることを示している.

\section{$3 \cdot 2 \cdot 2$ 実験結果}

\section{（1）予混合気特性の変化}

図 12 に，図 8 と同様にマスフローコントローラからの信号を用いて，マスフローコントローラが実際に流し ている燃料, 空気の流量から算出した, バーナ出口流速と当量比の変化を示す. 切り替えは, 流量一定の場合の 図 8 と同様, $\mathrm{t} \sim 3 \mathrm{~s}$ から $4 \mathrm{~s}$ の 1 秒の間に行われた. 図 12(a) より, バーナ出口流速は, 混合燃料を切り替えてい る間においても一定に保たれていることがわかる. また, (b) より, 当量比も, 切り替えている間も, 切り替え後 も 0.7 を維持しており, 当量比一定の条件が満たされていることがわかる.
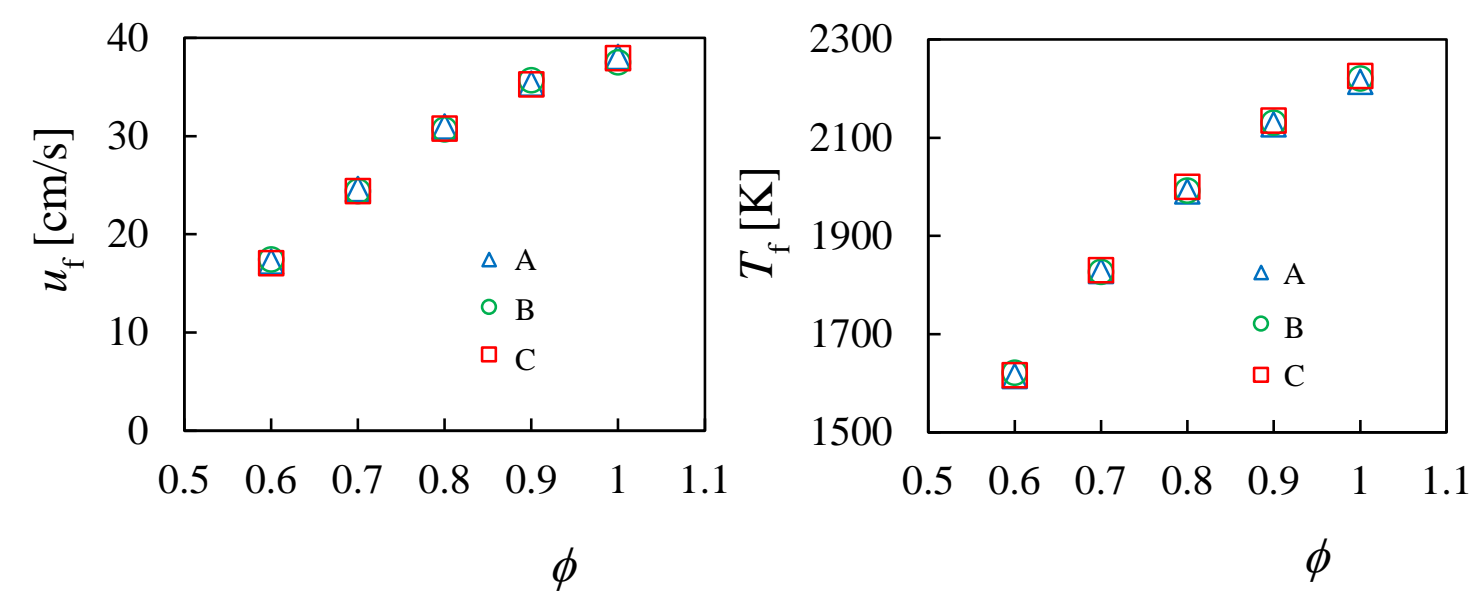

Fig. 11 Change in the flame speed and the flame temperature in the equivalence ratio constant case

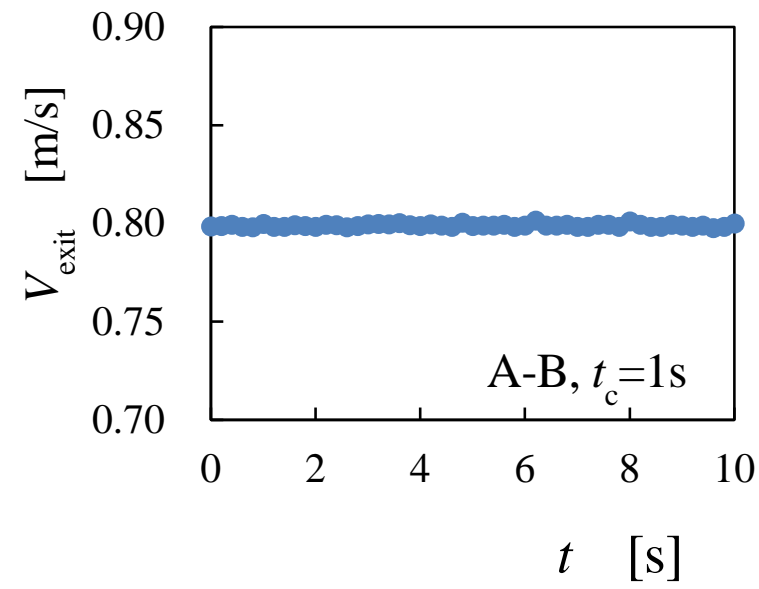

(a) Burner exit velocity

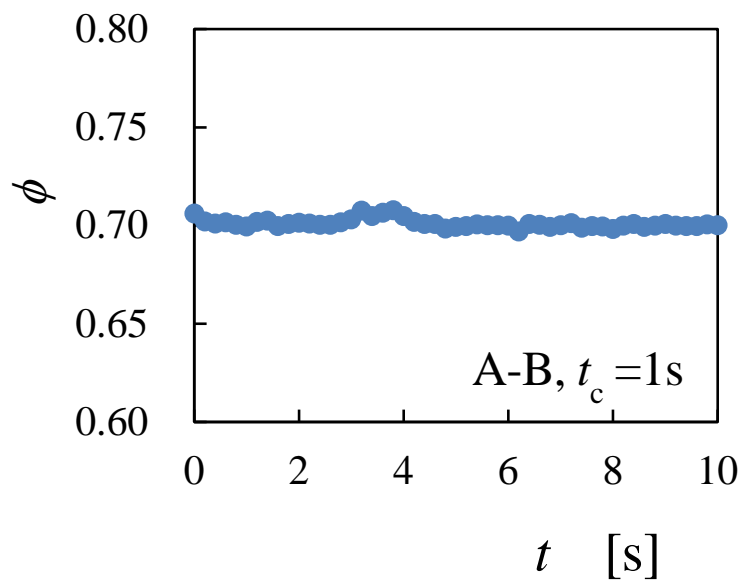

(b) Equivalence ratio

Fig. 12 Change in the burner exit velocity and the equivalence ratio in the equivalence ratio constant case 


\section{$3 \cdot 2 \cdot 3$ 火炎高さ変化}

図 13 に，混合燃料 A と B を切り替えた場合の火炎高さの変化を示す. (a) に A から B に切り替えた場合， (b) にB から A に切り替えた場合を示す．当量比を一定とした場合，図 11 に示寸ように，どの混合燃料の場合も， 火炎速度, 火炎温度ともほとんど変化しない. したがって, 火炎高さもほとんど変化していない. 図 14 に, 図 13 の縦軸の火炎高さのスケールを拡大したものを示す．全体で $0.3 \mathrm{~mm}$ 程度の変化があるが，これは，混合燃料のメ タン, エタン，プロパンの割合が変化することにより，Chemkin-pro による計算結果では図 11 に示すように混合 燃料によって顕著な違いは見られないが，実際の現象では火炎速度，火炎温度をはじめ，わずかではあるが燃焼 特性が変化することによるものと思われる. 図 9,10 の流量一定の場合の変化と比べると，その変化は十分小さ く，当量比一定の場合は，火炎高さはほとんど変化しないと考えることができる.

図 15 に，混合然料 A と C を切り替えた場合の火炎高さの変化を示寸. (a) に A から C に切り替えた場 合，(b) にC から A に切り替えた場合を示す．Ａ～B の切り替えの場合と同様，火炎高さはほとんど変化 していない. 図 16 に，図 15 の縦軸の火炎高さのスケールを拡大したものを示寸．全体で $0.6 \mathrm{~mm}$ 程度の変 化であり, 混合燃料 A と B の変化よりも大きな変化をしているが，変化時間に対応して変化しており，定 性的には，混合燃料 A と B の変化と同様である．混合燃料を C から A に流量一定の条件で切り替えた場 合，図 10(b) に示したように消炎が観察されたが，当量比一定の条件では消炎は観察されなかった. 図 11 に示したように，当量比を一定に保つことができれば，切り替え前後で火炎速度，火炎温度，火炎高さなど の燃焼特性はほとんど変化しないことから，メタン，エタン，プロパンの比率が異なり，発熱量が異なる混 合燃料を切り替えた場合であっても，燃焼の状態をほぼ同様に保つことができる.

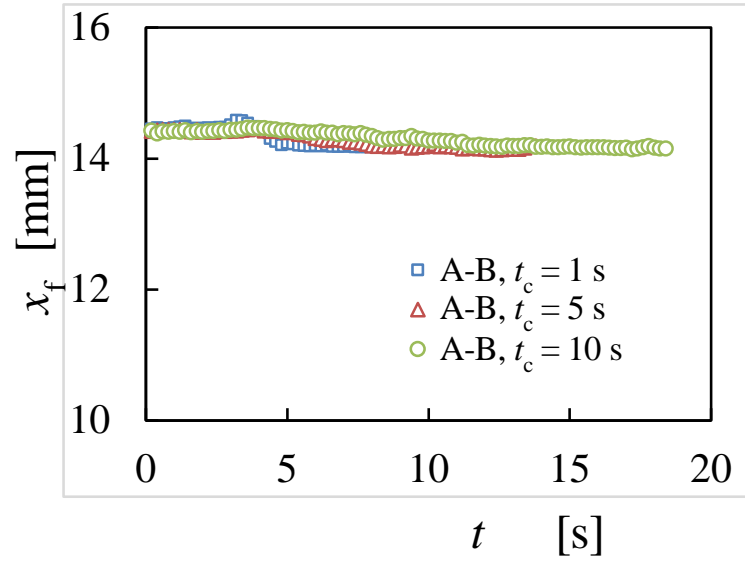

(a) Fuel mixture A to B

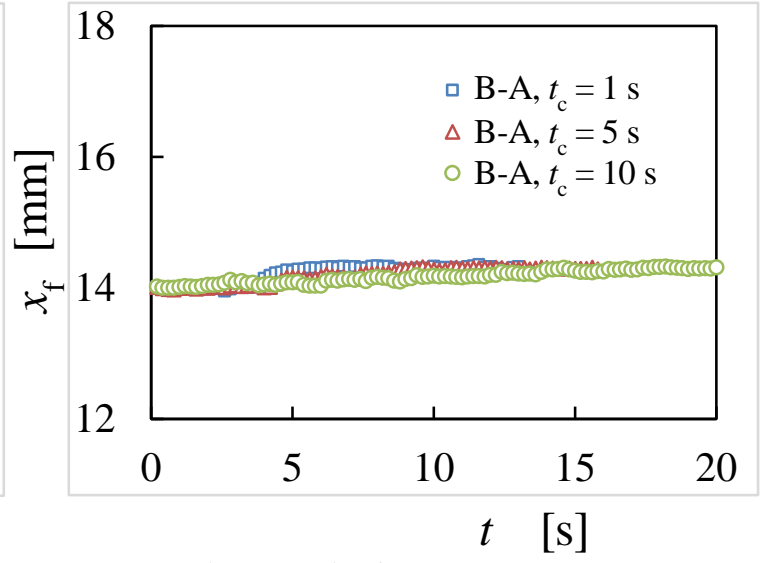

(b) Fuel mixture B to A

Fig. 13 Change in the flame height with the change in the fuel mixture A and $\mathrm{B}$ as a function of $t_{\mathrm{c}}$

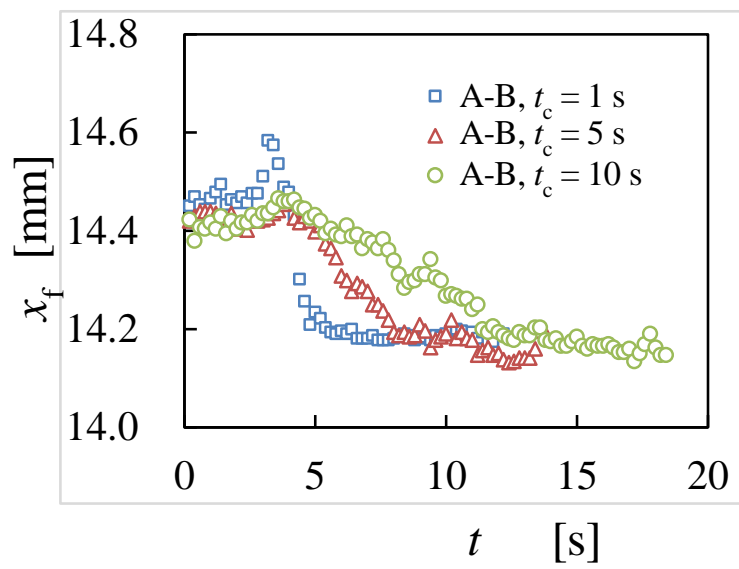

(a) Fuel mixture A to B

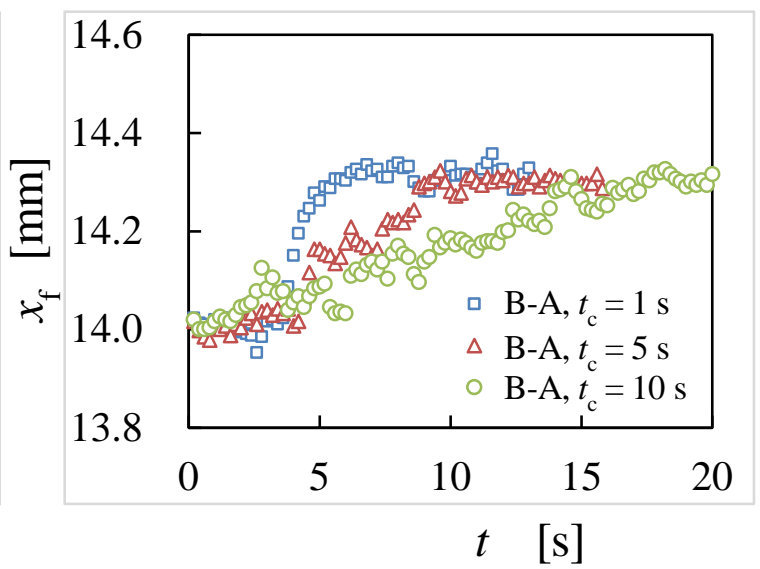

(b) Fuel mixture $\mathrm{B}$ to $\mathrm{A}$

Fig. 14 Details in the change in the flame height with the change in the fuel mixture A and $\mathrm{B}$ as a function of $t_{\mathrm{c}}$ 


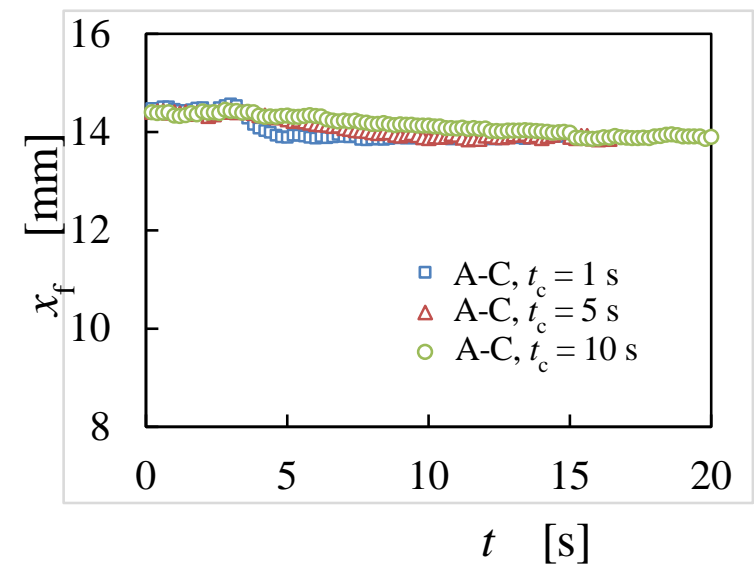

(a) Fuel mixture A to $\mathrm{C}$

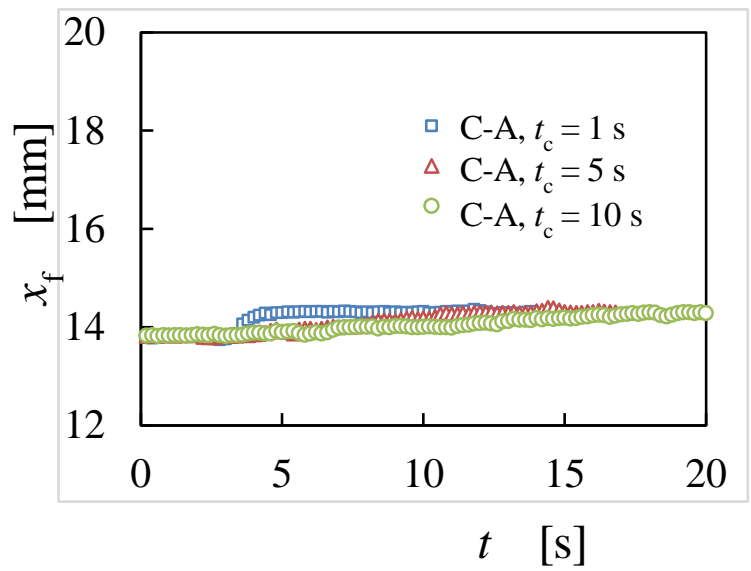

(b) Fuel mixture $\mathrm{C}$ to $\mathrm{A}$

Fig. 15 Change in the flame height with the change in the fuel mixture $\mathrm{A}$ and $\mathrm{C}$ as a function of $t_{\mathrm{c}}$

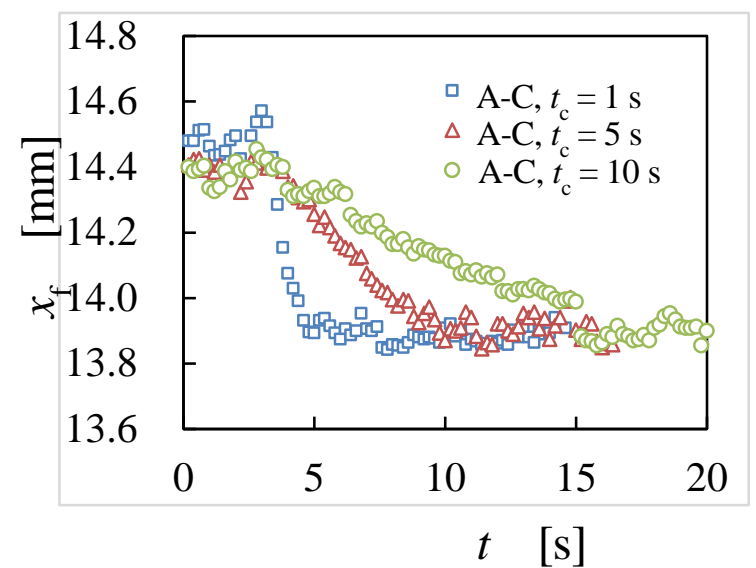

(a) Fuel mixture A to C

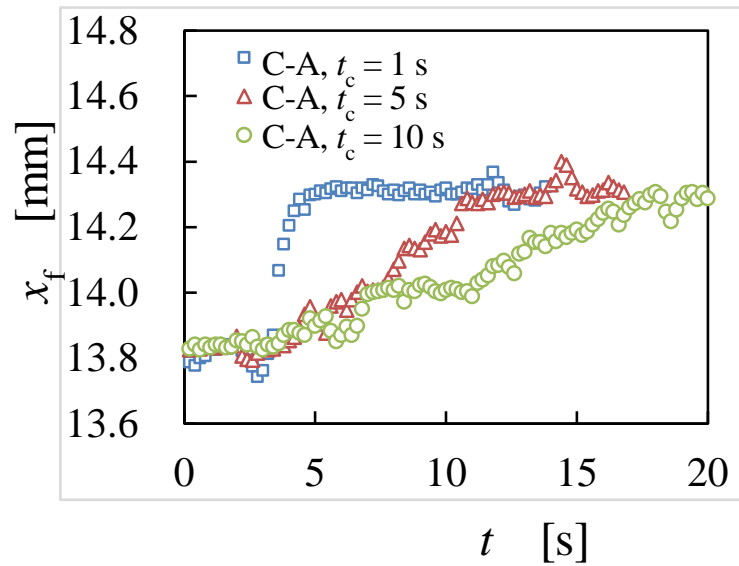

(b) Fuel mixture $\mathrm{C}$ to $\mathrm{A}$

Fig. 16 Details in the change in the flame height with the change in the fuel mixture $\mathrm{A}$ and $\mathrm{C}$ as a function of $t_{\mathrm{c}}$

\section{4. 混合燃料の切り替え方法に関する考察}

本研究では, メタン, エタン, プロパンの比率の異なる混合燃料を切り替えた場合の燃焼挙動への影響につい て検討を加えてきた．切り替え方法としては，もっとも簡便な切り替え方法であると考えられる，総流量を一定 に保ちながら, 混合燃料の流量を一定として切り替える方法と, 混合燃料の流量と空気流量を変化させて当量比 を一定に保ちながら切り替える方法について検討を加えた. 両者の火炎高さの変化の比較を図 17 に示す.

流量一定の場合，切り替えは容易であるが，当量比が変化してしまうため，切り替え前後で燃焼状態が変化す る. また，図 10 に示したように，消炎の可能性もある．他方，当量比一定の場合，火炎速度，火炎温度，火炎高 さなどの燃焼特性はほとんど変化させずに混合ガスを切り替えることができる.ただし，燃焼機器の燃焼状態を 当量比一定にするためには, 混合燃料の切り替えに伴って, 燃料流量と空気流量を変化させる必要がある. 通常, 混合燃料の切り替えは供給元側で, 燃料と空気の混合は使用機器側で行われる. この際, 燃料流量の切り替えを 行うと，流量は流路全体でほぼ同時刻に変化するが，濃度の変化は流路長分だけ遅れることになる，すると，使 用機器側の燃料と空気の混合部では，変化させた濃度の混合気が到達するまで，一時的に当量比が変化すること になる，そこで，使用機器で当量比一定としたい場合，供給元側と使用機器側で情報交換を行う必要がある. あ るいは, 使用機器側で燃料密度などを測定し, 燃料切り替えを検知し, 空気流量を調整するということも考えら れる.このような実用的な対応については，後さらなる検討が必要である. 


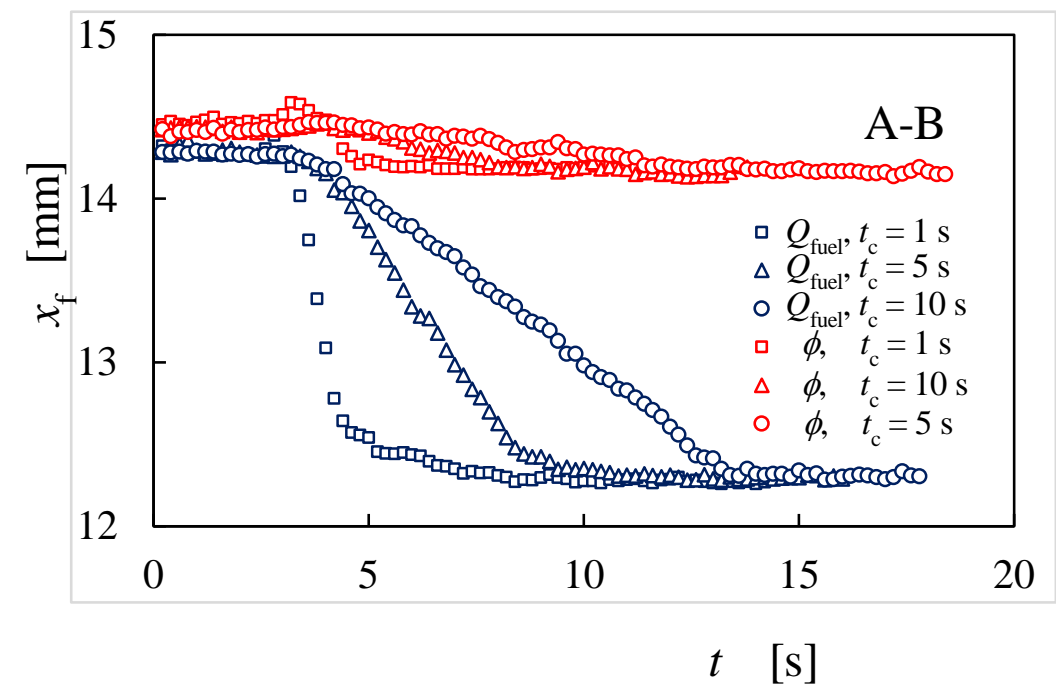

Fig. 17 Comparison of flame height variation

between the flow rate constant case and the equibalence ratio constant case

\section{5. 結言}

成分比の異なる混合燃料を過渡的に切り替えた場合の火炎挙動について，層流よどみ流予混合火炎を用いて検 討を加えた. 本研究では, 天然ガスを想定し, メタン, エタン, プロパンの 3 成分からなる混合燃料を対象にし た．切り替えは，混合燃料と空気の予混合気の総流量が一定となるように保ちながら混合燃料の流量を一定にし たまま切り替える流量一定の場合と，予混合気の当量比が一定となるように切り替える当量比一定の場合の二つ の場合について行った．また，切り替え時には，それぞれの流量を線形的に変化させた.

流量一定の場合, 空気および混合燃料の流量は一定となるようにするが, 成分比が変化するため, 当量比が変 化する. したがって, 切り替え前と切り替え後では, 火炎速度, 火炎温度などの燃焼特性が変化する. その結果, 火炎高さも顕著に変化する．また，成分比の違いが大きい場合，切り替え後の当量比がバーナの希薄可燃限界を 下回ることにより消炎することが確認された．この消炎は，切り替え後の当量比に起因していることから，切り 替え時間には無関係に生じる.

当量比一定の場合, 切り替え前, 切り替え中, 切り替え後, すべての過程で当量比一定となるように，各燃料 の流量および空気流量を変化させる. 本研究で対象とするメタン, エタン, プロパン混合気では, 当量比が一定 であれば，火炎速度，火炎温度はほぼ一定を保つことから，火炎高さもほとんど変化しない，したがって，混合 燃料を切り替えても燃焼の状態はほとんど変化することなく同様な状態を維持することができる．ただし，一般 的には混合燃料の切り替えは供給元で, 空気の導入は機器側で行われることが多く, 燃焼機器に導入される予混 合気の当量比を一定に保つためには，供給元と機器側での連携した制御が必要であると思われる.

\section{References}

Bourque, G., Healy, D., Curran, H., Zinner, C., Kalitan, D., de Vries, J., Aul, C. and Petersen, E., Ignition and flame speed kinetics of two natural gas blends with high levels of heavier hydrocarbons, Jounal of engineering for gas turbines and power, Vol. 132, No. 2 (2009), p. 21504.

Chemkin-Pro 15131, Reaction Design, (2013).

Huang, Z., Zhang, Y., Zeng, K., Liu, B., Wang, Q. and Jiang, D., Measurements of laminar burning velocities for natural gashydrogen-air mixtures, Combustion and flame, Vol. 146, No. 1-2 (2006), pp. 302-311.

Hikita, T. and Akita, K, Outline of Combustion -Physics and Chemistry of Flames-, Corona Publishing (1974), pp.190-199. 
Kawasaki,D., kashiwagi,K., Yokomori,T. and Ueda,T., Quisi-steady state to non-steady state transition criterion of laminar stagnating lean premixed flame with fuel concentration oscillation, Mechanical Engineering Letters, 2 (2016), pp. 1-8.

Law, C.K., Dynamics of stretched flames, Symposium on combustion, Vol. 22, No. 1 (1989), pp. 1381-1402.

Marzouk, Y.M., Ghoniem, A.F. and Najm, H.N., Dynamic response of strained premixed flames to equivalence ratio gradients, Proceedings of the combustion institute, Vol. 28, No. 2 (2000), pp. 1859-1866.

Mitu, M., Razus, D, Giurcan, V. and Oancea D., Normal burning velocity and propagation speed of ethane-air: Pressure and temperature dependence, Fuel, 147 (2015), pp. 27-34.

Miyamae,S., Rosdzimin, A.R.M., Tomita,H., Yokomori,T. and Ueda,T., Numerical investigation of the stagnating laminar premixed methane/air flame with fuel concentration oscillation using a four-step reaction mechanism, Mechanical Engineering Journal, 1 (2014), pp.1-15.

Rahman,M.R.A., Yokomori,T. and Ueda,T., Model of flame dynamics of laminar premixed flame subject to the low frequency equivalence ratio oscillations, International Communications in Heat and Mass Transfer, 61 (2015), pp.8-15.

Tomita, H., Rosdzimin, A.R.M., Miyamae,S., Yokomori,T. and Ueda,T., Flame dynamics of equivalence ratio oscillations in a laminar stagnating lean methane/air premixed flame, Proceedings of the Combustion Institute, 35 (2015), pp.969-997.

The International group of liquefied natural gas importers, The LNG Industries GIIGNL Annual Report 2016 Edition (2016).

U.S Energy Information Administration, Technically Recoverable Shale Oil and Gas Resource: An Assessment of 137 Shale Formations in 41 countries Outside the United State (2013).

Yamaoka, I. and Tsuji, H., Determination of burning velocity using counterflow flames, twentieth Symposium (International) on Combustion (1984), pp.1883-1892. 